\title{
Some Endocrine Traits of Transgenic Rabbits. II. Changes in Hormone Secretion and Response of Isolated Ovarian Tissue to FSH and Ghrelin
}

\author{
A. V. SIROTKIN ${ }^{1}$, P. CHRENEK ${ }^{1}$, K. DARLAK ${ }^{2}$, F. VALENZUELA ${ }^{2}$, Ž. KUKLOVÁ ${ }^{1}$ \\ ${ }^{1}$ Research Institute of Animal Production, Slovak Agricultural Research Centre, Nitra, Slovakia and \\ ${ }^{2}$ Peptides International, Inc., Louisville, Kentucky, USA
}

Received October 6, 2006

Accepted July 24, 2007

On-line October 11, 2007

\section{Summary}

In the present in vitro experiments we examined $\mathrm{FSH}$ - and ghrelin-induced changes in ovarian hormone secretion by transgenic rabbits. Fragments of ovaries isolated from adult transgenic (carrying mammary gland-specific mWAP-hFVIII gene) and non-transgenic rabbits from the same litter were cultured with and without FSH or ghrelin (both at $0,1,10$ or 100 $\mathrm{ng} / \mathrm{ml}$ medium). The secretion of progesterone $\left(\mathrm{P}_{4}\right)$, estradiol $\left(\mathrm{E}_{2}\right)$ and insulin-like growth factor I (IGF-I) was assessed by RIA. It was observed that ovaries isolated from transgenic rabbits secreted much less $P_{4}, E_{2}$ and IGF-I than the ovaries of nontransgenic animals. In control animals FSH reduced $E_{2}$ (at doses $1-100 \mathrm{ng} / \mathrm{ml}$ medium) and IGF-I (at $1-100 \mathrm{ng} / \mathrm{ml}$ ), but not $\mathrm{P}_{4}$ secretion, whereas ghrelin promoted $\mathrm{P}_{4}$ (at $1 \mathrm{ng} / \mathrm{ml}$ ) and IGF-I (at $100 \mathrm{ng} / \mathrm{ml}$ ), but not $E_{2}$ output. In transgenic animals, the effects were reversed: FSH had a stimulatory effect on $E_{2}$ (at 100 $\mathrm{ng} / \mathrm{ml}$ ) and ghrelin had an inhibitory effect on $\mathrm{P}_{4}$ (at $10 \mathrm{ng} / \mathrm{ml}$ ). No differences in the pattern of influence of FSH on $\mathrm{P}_{4}$ and IGF-I and of ghrelin on $E_{2}$ and IGF-I were found between control and transgenic animals. The present observations suggest that 1) both FSH and ghrelin are involved in rabbit ovarian hormone secretion, 2) transgenesis in rabbits is associated with a reduction in ovarian secretory activity, and 3) transgenesis can affect the response of ovarian cells to hormonal regulators.

\section{Key words}

Transgenesis • FSH • Ghrelin • Progesterone • Estradiol • IGF-I

\section{Corresponding author}

Alexander V. Sirotkin, Research Institute of Animal Production, Slovak Agricultural Research Centre, Hlohovska 2, 94992 Nitra, Slovakia. Fax: +421-37-6546480. E-mail: sirotkin@scpv.sk

\section{Introduction}

It was previously demonstrated (Sirotkin et al. 2008) that transgenesis (introduction of the mammary gland-specific mWAP-hFVIII gene) in rabbits can be associated with substantial changes in plasma and milk concentrations of corticosterone, progesterone $\left(\mathrm{P}_{4}\right)$, testosterone, estradiol $\left(\mathrm{E}_{2}\right)$ and insulin-like growth factor I (IGF-I). These hormonal changes can be associated with an increased incidence of pathological changes in organs, increases in number (Suvegová et al. 2004) and aneuploidy (Parkányi et al. 2004) of leucocytes in the blood, the appearance of new types of bone tissue, increased aneuploidy in bone marrow (Martiniaková et al. 2005) and changes in sperm quality (Chrenek et al. 2007). Nevertheless, it remains unknown whether these changes are mediated by central regulators (hypothalamohypophysial system) or whether transgenesis could target peripheral endocrine glands and their response to upstream hormonal regulators.

Gonadotropins (FSH, LH and related hormones) are the best known regulators of gonads. They can stimulate or inhibit ovarian steroid hormone secretion, either directly or through local IGF-I (Spies et al. 1997, Makarevich et al. 2000, Hillier 2001, Fair 2003, Mazerbourg et al. 2003). In contrast to gonadotropins, the role of the newly detected hormone ghrelin, which is produced in stomach and other tissues (van der Lely et al. 2004), in the control of the ovarian functions is poorly examined. There are two reports describing the ability of ghrelin to inhibit testosterone secretion and the expression of key steroidogenic enzymes in rat testis 
(Tena-Sempere 2005) and of its ability to stimulate the secretion of $\mathrm{P}_{4}, \mathrm{E}_{2}$, arginine-vasotocin and IGF-I in cultured chicken ovarian fragments (Sirotkin et al. 2006, Sirotkin and Grossmann 2007, 2008). The effect of ghrelin on hormone secretion by mammalian ovarian cells has not yet been studied.

The aim of present studies was to examine 1) whether both FSH and ghrelin are involved in the control of hormone secretion by rabbit ovarian cells, 2) whether transgenesis (introduction of mWAP-hFVIII gene) in rabbits is associated with changes in the secretory activity of ovarian cells, and 3) whether transgenesis is associated with changes in the response of ovarian cells to FSH and ghrelin. The secretion of $\mathrm{P}_{4}, \mathrm{E}_{2}$ and IGF-I was measured.

\section{Methods}

\section{Collection and culture of ovarian tissue}

The origin, housing, breeding and detection of transgenic broiler rabbits carrying the mammary gland specific WAP-hFVIII gene construct was described previously (Sirotkin et al. 2008). Ovarian tissue isolated from both transgenic and non-transgenic offspring from the same litters from $\mathrm{F}_{3}$ generation (adult sexually mature females, 9 months of age) was used. Ovarian function was activated by i.m. injection of pregnant mare serum gonadotropin (PMSG, Werfaser, Alvetra und Werfft, Vienna, Austria, $20 \mathrm{IU} / \mathrm{kg}$ body mass). One hour after injection, rabbits were killed at a local slaughterhouse in accordance with EU and local ethical and hygiene requirements. Ovaries were collected and transported to the laboratory at the ambient temperature in a glass container within $0.5 \mathrm{~h}$ of slaughter. Thereafter ovaries were washed in Dulbecco's PBS with $1 \%$ antibioticantimycotic solution (Sigma, St. Louis, USA), placed in $100 \mathrm{~mm}$ diameter culture dishes (Gama, České Budějovice, Czech Republic) and dissected using a blade knife to 8 approximately equal parts (weight 4.8-5.6 mg). These ovarian fragments were washed again 3 times in Dulbecco's PBS with antibiotic-antimycotic and cultured in $1 \mathrm{ml}$ of BioWhittaker ${ }^{\mathrm{TM}}$ DME/F12 1:1 mixture supplemented with $10 \%$ BioWhittaker $^{\mathrm{TM}}$ fetal calf serum (both from Cambrex BioScience, Verviers, Belgium) and $1 \%$ antibiotic-antimycotic solution (Sigma) in Falcon ${ }^{\mathrm{TM}}$ 24-well plates (Becton Dickinson, Lincoln Park, USA) at $37^{\circ} \mathrm{C}$ and $5 \% \mathrm{CO}_{2}$ in humidified air.

Control groups contained either no cells (blank control) or cells but without exogenous hormones. Experimental groups (originating from the ovaries of either transfected or non-transfected animals) received 1,10 or $100 \mathrm{ng} / \mathrm{ml}$ of immunological grade porcine FSH (pFSH-I-1, APF10640B) kindly provided by Dr. A.P.F. Parlow (National Hormone and Pituitary Program, Torrance, CA, USA) or research grade octanoylated recombinant human ghrelin 1-18 (PGH-3625 PI, Peptides International, Inc., Louisville, Kentucky, USA) prepared by solid phase peptide synthesis using an Fmoc/t-butyl strategy and purified on a reverse phase HPLC column. The hormones were dissolved in the culture medium immediately prior to the experiment. After $24 \mathrm{~h}$ culture the medium from plate wells was gently aspirated and frozen at $-18^{\circ} \mathrm{C}$ to await RIA.

\section{Validation of ovarian cells viability}

To determine the viability of ovarian cells after culture, all ovarian fragments were carefully dissected using a multiblade knife in Petri dishes with culture medium described above. The resulting suspension of granulosa cells was passed through a steel sieve to separate large pieces and cellular fragments, washed three times by centrifugation $(200 \mathrm{x} \mathrm{g})$ and resuspension in sterile incubation medium as above. $200 \mu \mathrm{l}$ aliquots of cell suspension were incubated in Lab-Tek chamberslides (Nunc, Inc., Naperville, USA) at $37{ }^{\circ} \mathrm{C}$ and $5 \%$ $\mathrm{CO}_{2}$ in humidified air during 5 days. Microscopic inspection after such culture showed the formation of about $70 \%$ confluent cell monolayer. Chamber-slides with monolayers were washed 3 times in ice-cold Dulbecco's PBS, fixed for $20 \mathrm{~min}$ in $4 \%$ paraformaldehyde in Dulbecco's PBS, washed in PBS $(2 \times 5 \mathrm{~min})$ and subjected to immunocytochemical analysis by using DAB-reagent for visualization of PCNA (marker of proliferation) and bax (a marker of apoptosis), as described previously (Makarevich et al. 2000, Sirotkin et al. 2006).

\section{Hormone analysis}

Concentrations of $\mathrm{P}_{4}, \mathrm{E}_{2}$ and IGF-I contained in ovarian fragments-conditioned incubation medium were determined in 20-50 $\mu$ l of medium using RIA/IRMA kits from DSL (Webster, TX, USA) according to the manufacturer's instructions. The characteristics of the assay were described previously (Sirotkin et al. 1998, Makarevich et al. 2000, 2004).

\section{Statistics}

Each experimental group was represented by six culture wells, each containing one ovarian fragment. The 


\section{PCNA}

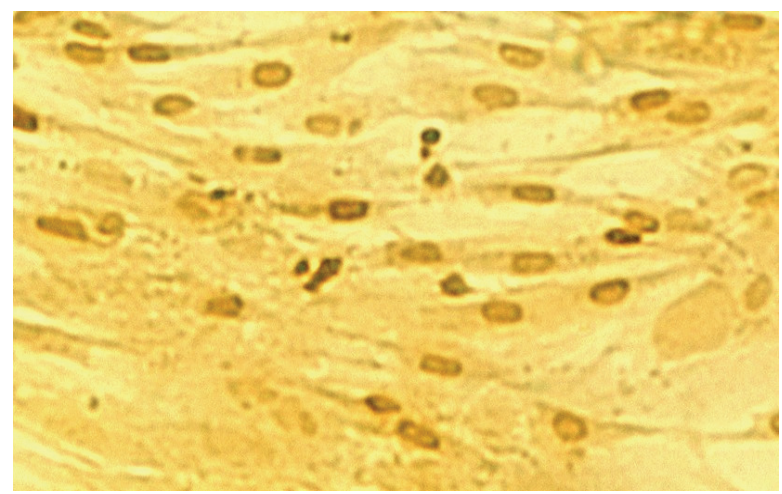

Bax

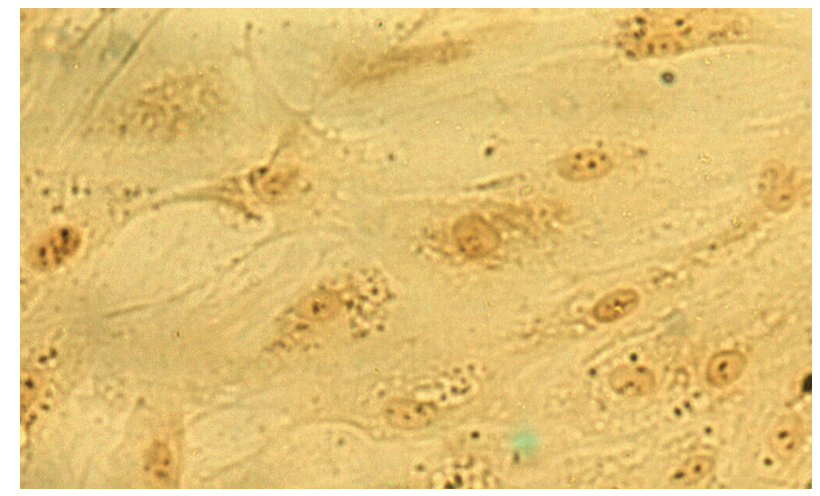

Fig. 1. Monolayers of ovarian cells isolated from cultured ovarian fragments of non-transgenic (control) rabbits and expressing markers of proliferation (PCNA, left) and apoptosis (bax, right, dark staining). Magnification x 200.

data shown are the values obtained in two different series of experiments: one to examine the effect of FSH and the other to detect the effect of ghrelin. The experiments were performed on separate days, using separate pools of cells, each obtained from 3 control and 3 transgenic animals. After RIA, the values of the blank control (cellfree medium) were subtracted from the value determined in cell-conditioned medium to exclude any non-specific background. The rates of substance secretion were calculated per mg ovarian tissue and day. Significant differences between the experiments were evaluated using two-way ANOVA. When effects of treatments were revealed, data from the experimental and control groups were compared by Duncan's multiple range test. Differences from the control at $\mathrm{P}<0.05$ were considered as significant.

\section{Results}

The cultured ovarian fragments secreted substantial amounts of $\mathrm{P}_{4}, \mathrm{E}_{2}$ and IGF-I. Cells isolated from ovarian fragments after one day culture were able to attach to the substrate and form a monolayer. Immunocytochemical analysis of these cells showed the presence of substances associated with proliferation (PCNA, localized mainly in nuclei) and apoptosis (bax, localized both in nuclei and cytoplasma) (Fig. 1).

Significant differences were found between the basal secretory activities of ovarian cells originating from transgenic and non-transgenic animals. In the first series of experiments the cells of transgenic rabbits secreted much less $\mathrm{P}_{4}$ (Fig. 2a) and $\mathrm{E}_{2}$ (Fig. 2b), but not IGF-I (Fig. 2c) than those of non-transgenic animals. In the second series of experiments, ovarian cells from transgenic rabbits secreted significantly less $\mathrm{P}_{4}$ (Fig. 3a), $\mathrm{E}_{2}$ (Fig. 3b) and IGF-I (Fig. 3c) compared with nontransgenic ones.

FSH as able to affect the secretion of some hormones by cultured ovarian fragments, whilst its effect depended on the origin of ovarian tissue. It reduced the secretion of $\mathrm{E}_{2}$ (Fig. 2b) and IGF-I (Fig. 2c), but not $\mathrm{P}_{4}$ secretion by control ovarian tissue. The response of ovarian tissue from transgenic animals on FSH was similar in the case of $\mathrm{P}_{4}$ (Fig. 2a) and IGF-I (Fig. 2c). However, in transgenic rabbits addition of FSH resulted not in inhibition but in stimulation of $E_{2}$ secretion (Fig. 2b).

The influence of ghrelin on secretory activity of ovarian tissue was demonstrated in both groups. With control cells it stimulated $\mathrm{P}_{4}$ (Fig. 3a) and IGF-I (Fig. 3c), but not $\mathrm{E}_{2}$ (Fig. 3b) secretion. With transgenic cells, ghrelin inhibited $\mathrm{P}_{4}$ secretion (Fig. 3a). No significant differences were found between the groups in the pattern of influence of ghrelin on $\mathrm{E}_{2}$ (Fig.3b) and IGF-I (Fig. 3c).

\section{Discussion}

Our observations confirm previous findings (Makarevich et al. 2000) of the ability of isolated and cultured rabbit ovarian cells to survive, to form monolayer, to express markers of proliferation and to secrete steroid hormones. Our observations confirm previous reports (Spies et al. 1997, Hillier 2001) of production of steroid hormones by rabbit ovarian cells. This is probably the first demonstration of the presence of the apoptosis-associated substance bax and of the 
A.

Effect of FSH on the release of progesterone by ovarian fragments of normal and transgenic rabbits

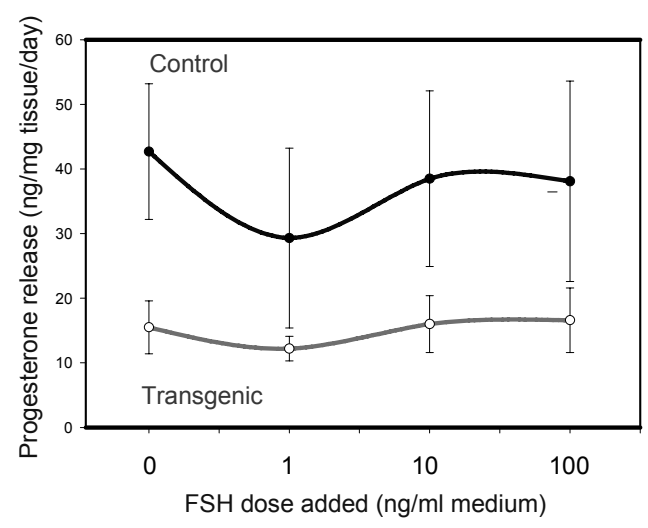

B.

Effect of FSH on the release of estradiol by ovarian fragments of normal and transgenic rabbits

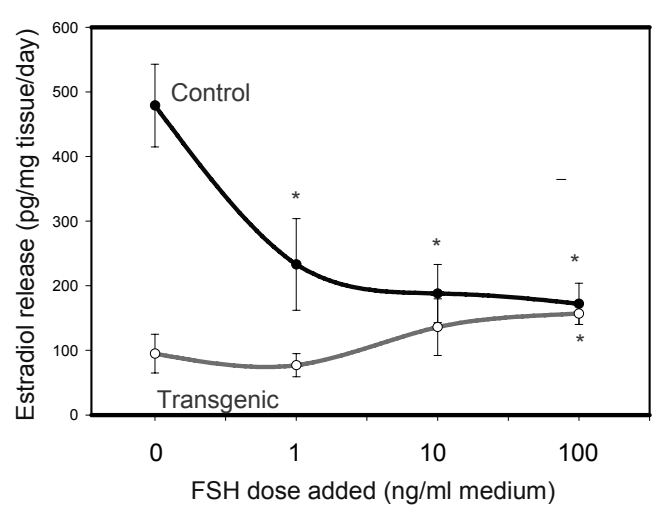

C.

Effect of FSH on the release of IGF-I by ovarian fragments of normal and transgenic rabbits

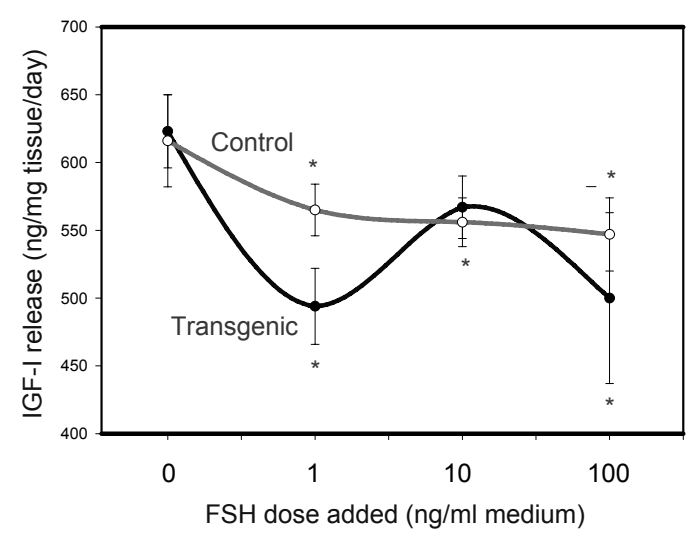

Fig. 2. Effect of FSH on the secretion of $\mathrm{P}_{4}(\mathbf{A}), \mathrm{E}_{2}$ (B) and IGF-I (C) by cultured fragments of ovaries isolated from non-transgenic (control) and transgenic rabbits. Values are means \pm S.E.M. * significant $(p<0.05)$ difference between control and transgenic animals.

secretion of IGF-I by rabbit ovaries.

Results presented in Figure 2 confirm previous data (Spies et al. 1997, Hillier 2001) on the involvement of FSH in the control of rabbit ovarian steroidogenesis. The lack of influence of FSH on $\mathrm{P}_{4}$ and the inhibitory action of FSH on $\mathrm{E}_{2}$ observed in our experiments could be due to FSH-induced luteinization of rabbit ovarian tissue, which in rodents is associated with a reduction in $\mathrm{E}_{2}$ production, but not with the formation of a progesterone-producing corpus luteum (Hillier 2001). This effect of FSH on steroidogenesis could also be explained by the development of negative feedback mechanisms induced by PMSG injection before collection of the ovaries. This is the first report of the ability of FSH to control rabbit IGF-I. As in other mammals (Makarevich et al. 2000, Fair 2003, Mazerbourg et al. 2003, Oksbjerg et al. 2004), this could regulate basic ovarian functions and mediate FSH action.

Figure 3 shows a direct influence of ghrelin on mammalian ovarian function. Previously, only an indirect influence of ghrelin on reproduction, mediated by metabolism or hypothalamo-hypophysial system, had been suggested (van der Lelly et al. 2004, Tena-Sempere 2005). The influence of ghrelin on both $\mathrm{P}_{4}$ and IGF-I observed in our experiments is the first demonstration of involvement of ghrelin in direct control of secretion of both peptide and steroid ovarian hormones. Furthermore, it indicates potential involvement of ghrelin in regulation of ovarian functions controlled by these hormones in mammals. This finding is in line with our recent observation that ghrelin can regulate the secretory activity, proliferation and apoptosis of cultured avian ovarian cells (Sirotkin et al. 2006, Sirotkin and Grissmann 2007, 2008).

The results presented in Figures 2 and 3 demonstrate that transgenesis may be associated with substantial changes in ovarian secretory activity: ovarian cells isolated from transgenic rabbits had a reduced ability to secrete both steroid and peptide hormones. This observation is in agreement with the results of our in-vivo experiments (Sirotkin et al. 2008) demonstrating that transgenic rabbits had altered (mainly reduced) concentrations of peptide and steroid hormones in blood. A certain discrepancy between these two figures in the 
A.

Effect of ghrelin on the release of progesterone by ovarian fragments of normal and transgenic rabbits

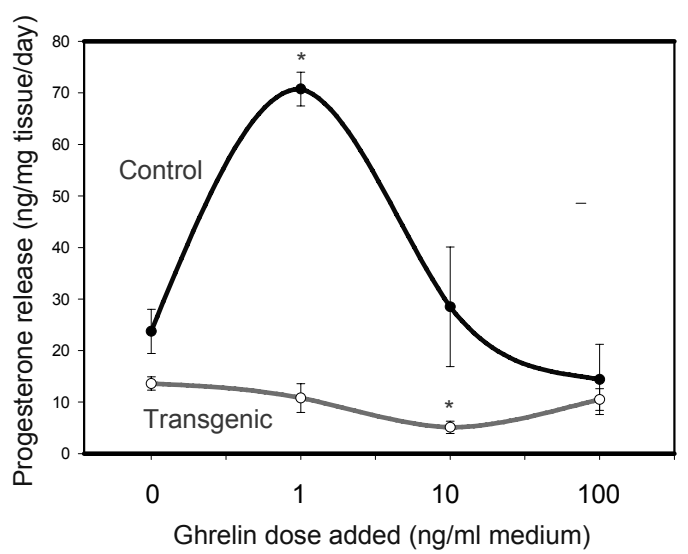

B.

Effect of ghrelin on the release of estradiol by ovarian fragments of normal and transgenic rabbits

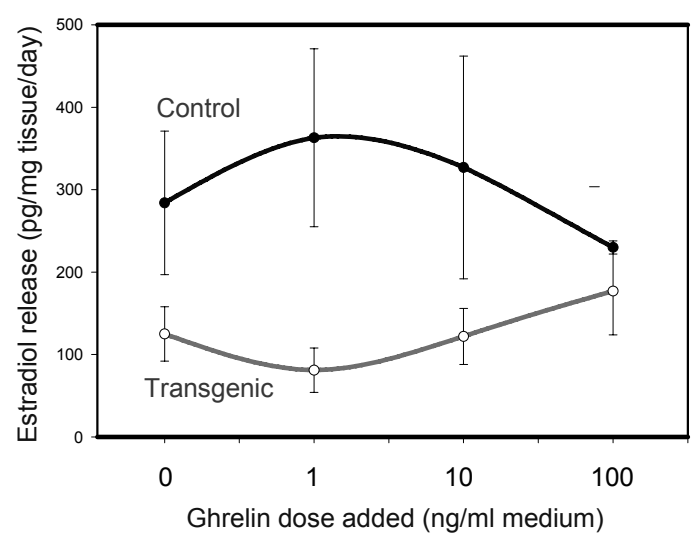

C.

Effect of ghrelin on the release of IGF-I by ovarian fragments of normal and transgenic rabbits

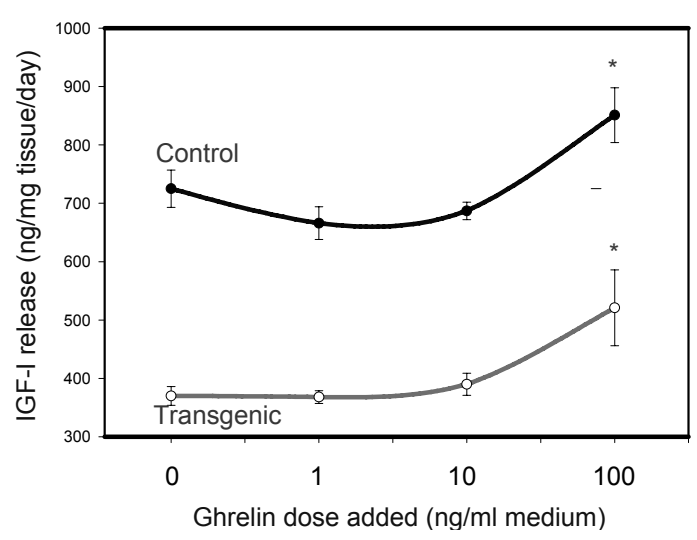

Fig. 3. Effect of ghrelin on the secretion of $P_{4}(\mathbf{A}), E_{2}(\mathbf{B})$ and IGF-I (C) by cultured fragments of ovaries isolated from nontransgenic (control) and transgenic rabbits. Values are means \pm S.E.M. * - significant $(p<0.05)$ difference between control and transgenic animals.

effect of transgenesis on basal IGF-I release could be due to some random differences in material used in different experiments, but in the majority of cases ovarian cells isolated from transgenic rabbits secreted significantly lover amounts of hormones than the cells of control animals. The reduced secretory activity of ovarian cells isolated from transgenic rabbits demonstrates that transgenesis may affect the endocrine system not (or not only) at the hypothalamo-hypophysial level, but directly at peripheral endocrine glands (ovaries).

The present figures showed not only transgenesis-associated changes in basal ovarian secretory activity but also the principal changes in ovarian cell response to FSH and ghrelin treatments. Transgenesis was associated with prevention and even reversal of the $\mathrm{E}_{2}$ response to $\mathrm{FSH}$ and $\mathrm{P}_{4}$ response to ghrelin treatment. Since $\mathrm{FSH}, \mathrm{P}_{4}$ and $\mathrm{E}_{2}$ (Spies et al. 1997, Hillier 2001) and probably ghrelin (Tena-Sempere 2005, Sirotkin et al. 2006) are important regulators of the ovary, it is possible that transgenesis influences reproduction through these hormones. Indeed, transgenesis with the mWAP-hFVIII gene construct results in changes in sperm quality (Chrenek et al. 2007) but has no effect on female fertility (Sirotkin et al. 2008).

The mechanisms through which transgenesis influences ovarian secretory activity remain to be studied. Some changes may be primary and others secondary. For example, transgenesis-associated suppression of the $\mathrm{P}_{4}$ and $E_{2}$ observed in our experiments could be due to decreased secretion of IGF-I, a known stimulator of ovarian steroidogenesis (Makarevich et al. 2000, Fair 2003, Mazerbourg et al. 2003, Oksbjerg et al. 2004) or to a decreased response of ovarian cells to ghrelin, which was potent stimulator of both IGF-I and $\mathrm{P}_{4}$ secretion in our experiments. Therefore, the trangenesis of rabbits with mWAP-hFVIII gene construct could affect endocrine and other systems probably not through hFVIII itself (Chrenek et al. 2005b, Sirotkin et al. 2008) but rather through destabilization of the genotype, which in turn affects the production, secretion, reception or response to several important hormones. Our studies have demonstrated that transgenesis itself, independently of the introduced gene, could have unpredicted side effects on the endocrine system, including suppression of ovarian 
hormone secretion and reversal of the response of ovarian cells to upstream hormonal regulators.

\section{Conflict of Interest}

There is no conflict of interest.

\section{Acknowledgements}

The authors express their deep gratitude to Mrs. K. Tothová and Mr. J. Pecho for skillful technical assistance during collection the ovaries and hormone analysis and to Dr. J. Rafay for help in animal care and management. These studies were supported by the Slovak Academy of Science (grant 2003 SP51/0280900/ 0280903).

\section{References}

CHRENEK P, KAUFMANN V, MAKAREVICH AV, BAUER M, RYBAN L, UHRÍN P, PALEYANDA RK, BINDER BR: Production of recombinant human clotting Factor VIII in mammary gland of two transgenic rabbit lines. Proc $49^{\text {th }}$ GTH meeting, Mannheim, 2005b, poster P118.

CHRENEK P, TRANDZIK J, MASSANYI P, MAKAREVICH A, LUKÁČ N, PEŠKOVIČOVÁ D, PALEYANDS RK: Effect of transgenesis on reproductive traits of rabbit males. Animal Reprod Sci 99: 127-134, 2007.

FAIR T: Follicular oocyte growth and acquisition of developmental competence. Anim Reprod Sci 78: 203-216, 2003.

HILLIER SG: Gonadotropic control of ovarian follicular growth and development. Mol Cell Endocrinol 179: 39-46, 2001.

MAKAREVICH A, SIROTKIN AV, CHRENEK P, BULLA J, HETÉNYI L: The role of IGF-I, cAMP/protein kinase A and MAP-kinase in the control of steroid secretion, cyclic nucleotide production, granulosa cell proliferation and preimplantation embryo development in rabbits. J Steroid Biochem Mol Biol 73: 123-133, 2000.

MAKAREVICH AV, SIROTKIN AV, GENIESER HG: Action of protein kinase A regulators on secretory activity of porcine granulosa cells in vitro. Anim Reprod Sci 81: 125-136, 2004.

MARTINIAKOVÁ M, OMELKA R, CHRENEK P, RYBAN L, PARKÁNYI V, GROSSKOPF B, VONDRÁKOVÁ M, BAUEROVÁ M: Changes of femoral bone tissue microstructure in transgenic rabbits. Folia Biol (Praha) 51: 140-144, 2005.

MAZERBOURG S, BONDY CA, ZHOU J, MONGET P: The insulin-like growth factor system: a key determinant role in the growth and selection of ovarian follicles? A comparative species study. Reprod Domest Anim 38: 247$258,2003$.

OKSBJERG N, GONDRET F, VESTERGAARD M: Basic principles of muscle development and growth in meatproducing mammals as affected by the insulin-like growth factor (IGF) system. Domest Anim Endocrinol 27: 219-240, 2004. OK?

PARKÁNYI V, CHRENEK P, RAFAY J, SUVEGOVÁ K, JURČÍK R, MAKAREVICH AV, PIVKO J, HETÉNYI L, PALEYANDA RK: Aneuploidy in the transgenic rabbit. Folia Biol (Praha) 50: 194-199, 2004.

SIROTKIN AV, GROSSMANN R: The role of ghrelin and some intracellular mechanisms in controlling the secretory activity of chicken ovarian cells. Com Biochem Physiol A 147: 239-246, 2007.

SIROTKIN AV, GROSSMANN R: Effects of ghrelin and its analogues on chicken ovarian granulosa cell. Dom Animal Endocrinol 34: 125-134, 2008.

SIROTKIN AV, MAKAREVICH AV, KOTWICA J, MARNET P-G, KWON HB, HETENYI L: Isolated porcine ovarian follicles as a model for the study of hormone and growth factor action on ovarian secretory activity. J Endocrinol 159: 313-321, 1998.

SIROTKIN AV, GROSSMANN R, MARIA-PEON MT, ROA J, TENA-SEMPERE M, KLEIN S: Novel expression and functional role of ghrelin in chicken ovary. Mol Cell Endocrinol 257-258: 15-25, 2006.

SIROTKIN AV, CHRENEK P, RAFAY J, OMELKA R, VETR H, JURČÍK R, BINDER BR: Some endocrine traits of transgenic rabbits. I. Changes in plasma and milk hormones. Physiol Res 57: this issue, 2008.

SPIES HG, PAU KY, YANG SP: Coital and estrogen signals: a contrast in the preovulatory neuroendocrine networks of rabbits and rhesus monkeys. Biol Reprod 56: 310-319, 1997. 
SUVEGOVÁ K, JURČÍK R, CHRENEK P, VAŠÍČEK D, GAŽIČOVÁ Z, RAFAY J, HANUŠOVÁ E: Comparison of inner organs weight and selected hematological and biochemical blood parameters of transgenic and nontransgenic rabbits. Proc 8th World Rabbit Congress, Mexico, 2004, pp 632-638.

TENA-SEMPERE M: Exploring the role of ghrelin as novel regulator of gonadal function. Growth Horm IGF Res $\mathbf{1 5}$ : 83-88, 2005.

VAN DER LELY AJ, TSCHOP M, HEIMAN ML, GHIGO E: Biological, physiological, pathophysiological, and pharmacological aspects of ghrelin. Endocr Rev 25: 426-457, 2004. 